\title{
Imagination and Literacy Instruction: A Content Analysis of Literature within Literacy-Related Publications
}

\author{
CAROLE PELTTARI \\ The College at Brockport: State University of New York
}

\begin{abstract}
Through content analysis of research conducted during the last 25 years, this paper identifies five vital uses of imagination within literacy instruction. First, readers use imagination to comprehend text. Second, readers use imagination to engage in the world depicted through the text. Third, readers use imagination to make sense of both narrative and expository texts. Fourth, readers use imagination to learn about self and others. Finally, readers benefit from instruction regarding the use of imagination to enhance reading. A compilation of instructional methods is presented. This analysis establishes the need for classroom instruction connecting imagination and literacy.
\end{abstract}

There, in the night, where none can spy,

All in my hunter's camp I lie, And play at books that I have read

Till it is time to go to bed.

These are the hills, these are the woods,

These are my starry solitudes;

And there the river by whose brink

The roaring lions come to drink.

Excerpt from "The Land of Story Books” by Robert Louis Stevenson (1885)

\section{Introduction}

Imagination is so essential to meaningful reading that the National Endowment for the Arts (2007) labeled reading "an act requiring great resources of memory, imagination, and intent questioning" (p. 44). Children imagine intuitively, but educators are wise to recognize the power of imagination to impact literacy instruction and practice (Enciso \& Shanahan, 1993). Like Robert Louis Stevenson 130 years ago, children today read and imagine and are transported to places they have never seen. Still, children can benefit from explicit teaching that links imagination and literacy. This content analysis was undertaken to determine what has been written and researched during the last twenty-five years regarding connections between imagination and literacy instruction. While Brill, in 2004 stated, "the status of imagination in education is somewhat insecure" (p. 84), in 2015 Hall, O'Hare, Santavicca and Jones declared the use of imagination in literacy is not only insecure but unprivileged. The documented use of imagination receives little attention in the practice of literacy instruction (Hall, et al. 2015; Routman, 2003), yet experience and neuroscience suggest readers use deep levels of thinking to make sense of texts (Anderson, 2013; Hruby \& Goswami, 2011; Pelttari \& Marchetti, 2014).

This content analysis verifies, for the field, the scant literature regarding methods for incorporating imagination into literacy instruction and presents implications garnered from the few 
studies identified. Nevertheless, calls for incorporating imagination into instruction while teaching basic skills have continued throughout the twenty-five years studied. As Clay (1991), the founder of Reading Recovery, emphasized throughout her career, we want children to process text successfully. Yet, when Clay discusses children learning to read independently, she recognizes the importance of social and imaginative interactions as well as decoding processes. Spencer (2002), another eminent literacy researcher and writer for four decades, questions current instruction that moves away from "the acknowledged link between symbolic play and interactions with storybooks" (p. 107). Spencer's concern is that focus on basic skills has led to "less continuous reading of complete texts" (p. 107). Through this content analysis, I present research that identifies methods of incorporating imagination positively into literacy instruction.

\section{Significance}

Research shows that if students receive a steady diet of skills without opportunity to engage with texts in interesting and meaningful ways, students do not connect reading and writing to pleasurable activities, and therefore, do not recognize purposes for reading and writing outside the classroom (Layne, 2009; Wilhelm \& Smith, 2014). The converse is also true: if students have opportunity to engage with texts in interesting and meaningful ways, more students choose to read and write both inside and outside the classroom (Emig, 1971; Wilhelm \& Smith, 2014). This study is significant because it highlights instructional uses of imagination, an important tool. I identified four ways readers use imagination. I also documented benefits of instructing readers to use imagination. In the end, this analysis establishes a research base that verifies some effects of imagination on literacy learning and calls for additional research.

This research is also significant because I have reviewed the scant research, at least in three publications, over the last twenty-five years. Spencer (2002) states that while the definition of imagination is elusive, imagination is the most overlooked component "in the learning and teaching of reading and writing" (p. 105). For this content analysis, I reviewed current, recent, and historical research in three journals, finding the word imagination in only thirty-four articles over the last twenty-five years. Four of those articles appeared in 2004 (Brill; Douville \& Algozzine; Schofield \& Rogers; Wood \& Endres), possibly as a reaction to Spencer's statement in 2002. Three of the articles printed in 2004 involved research. However, in the sample reported here, research regarding imagination and literacy was sporadic before Spencer's declaration and declined sharply after 2004. The next two research articles appeared in 2007 (Walsh; Roser, Martinez, Fuhrken, \& Mcdonnold). In the last nine years only four research articles related to literacy and imagination appeared in the journals analyzed for this content analysis. In 2010 (Peskin, Allen, \& WellsJopling), 2012 (Hannaford), 2013 (Maine) and 2015 (Lysaker \& Sedberry), single research articles related to literacy and imagination were printed. Of the four related articles printed since 2010, three appeared in one journal: Literacy. Therefore, it appears Spencer's most "taken for granted" (p. 105) component of literacy instruction is still taken for granted, at least in research reported in the literacy publications analyzed for this study.

The definition of imagination truly is elusive (Spencer, 2002) since writers seldom define the term. In twenty-nine of the thirty-four articles identified for this content analysis, the term imagination is used as a commonplace or presupposed activity. In such cases, instructional methods are not identified and may or may not be assumed. Brill (2004), who qualitatively analyzed letters written by eleven-year-old children, suggested that though imagination plays a significant role in literacy learning and practice, imagination "can easily be marginalised or undervalued due, in part, to difficulties of definition" (p. 84). 
While some researchers' definitions or references suggest visual images lead to imagination (Maine, 2013; McTigue, 2010; Serafini \& Moses, 2014), other researchers suggest multi-sensory input affects imagination (Douville \& Algozzine, 2004; Hannaford, 2012; Roser et al, 2004; Wood \& Endres, 2004). Hannaford suggests imagination forms a bridge between the reader's senses and thoughts (Hannford, 2012). Some researchers also tie imagination to previous experiences (Wood \& Endres) while other researchers see imagination as a more inventive power (King, 2007). King considers imagination "the capacity to wonder, to consider what is not but could be" (p. 215). And Spencer (2002) suggests imagination allows people to "realize how things might, or could, be otherwise" (p.110). I add my voice to King's and Spencer's, agreeing that imagination is augmented by, but not dependent on, previous experiences. Beyond the retrieval of previously-held images, the power of spoken and written language allows listeners and readers to employ imagination to create new worlds and wonders.

\section{Conceptual Framework}

Four important concepts undergird this research: reading is a responsive activity, mental imagery supports reading comprehension, oral literacy contributes to print literacy, and identity and literacy intertwine. 1) Readers respond to text. Rosenblatt (1978) suggests that if readers truly engage with text, "there is an element of creativity in even the simplest reading act" (p. 51). The very act of reading or writing is an experience (Rosenblatt, 1938/1995). 2) Imagination involves incorporating mental imagery instruction into literacy instruction. Paivio (1971) and Pressley (1977) present seminal research regarding ways mental imagery supports reading comprehension. Pressley determined that teachers' prompts can influence children to develop images that help the children remember content they read. Sadoski \& Paivio (2013) continue reporting connections between mental imagery and reading comprehension. 3) Auditory and oral components of literacy contribute basic skills related to reading skills. Dyson \& Genishi (2013) relate both oral and written language to “young children's entry into school practices" (p. 169). Nystrand's (2006) examination of 150 years of research confirms social and dialogic connections important to reading instruction. 4) Identity and literacy are closely aligned. Gee (2004) offers evidence of children reading as a result of identifying themselves as readers. Other researchers agree that reading and identity formation are intertwined intricately (Ivey \& Johnston, 2013; McCarthey \& Moje, 2002; Moje \& Luke, 2009). The four elements of this theoretical framework weave around and through each other in the research analyzed in this paper.

\section{Methods}

Through conventional content analysis (Hoffman, Wilson, Martinez \& Sailors, 2011), I inductively developed codes and then themes (Hsieh \& Shannon, 2005). First I conducted between-study analysis (Onwuegbuzie, Leech \& Collins, 2012) to identify use of the term imagination in peer-reviewed articles within journals dedicated to the field of literacy. The search was limited to the named journals because those journals are targeted toward practitioners, are printed in English and represent two respected literacy organizations. Using Academic Search Complete, an electronic database, I searched the content of three journals, Literacy, The Reading Teacher, and Journal of Adolescent and Adult Literacies (JAAL), to find connections between literacy and imagination. Since literacy and literacy learners are the main foci of the named journals, I sought connections through references to the term imagination. Literacy is published by Wiley-Blackwell for the United Kingdom Literacy Association (UKLA), serving educators and the public regarding broad aspects of literacy for preschoolers through adults. The Reading 
Teacher and JAAL are published by Wiley for the International Literacy Association. The Reading Teacher offers research-based articles related to literacy learning for children up to age twelve while JAAL offers research-based articles related to literacy learners older than age twelve. With this sample, all age levels were represented twice. Using the term imagination, the search engine found seven, nineteen, and eight articles respectively within Literacy, The Reading Teacher, and $J A A L$, during the last twenty-five years. However, the electronic data base included the full twentyfive years for only The Reading Teacher; representation began in 1995 for JAAL and 2004 for Literacy. I used snowballing to a limited extent, reviewing additional books and articles already known to me or cited in the listed articles. For instance, I was aware of King's (2007) and Miller's (1997) texts due to earlier research I had conducted regarding imagination. Works by Douville, Gambrell and Langer, with a variety of research partners, warranted analysis because their research articles were repeatedly referenced in other primary sources in this review.

Within each article identified, I activated the search button on a pdf copy, seeking the term imagin*. The truncated form of imagination was used in order to identify related terms. Terms found and reviewed included imagination, imaginative, imaginatively, imagine, imagines, imagined, and imaging. After searching four articles (Walsh, 2007; Maine, 2013; Hannaford, 2012; Hall \& Jones, 2016), five categories emerged: year of publication, definition of imagination (or lack of definition), the number and forms of imagin*, the purpose of the article, and quotes establishing key ideas related to imagination. The initial four articles were randomly chosen from Literacy. I started with that journal because I regularly read that journal and knew recent research in Literacy connected literacy and imagination. Nine additional articles were analyzed before a sixth category emerged: connections to literacy skills or instruction. I did not add the sixth category to the original thirteen articles, but the final category helped sharpen the focus of the remaining analyses. In the end, data were collected from a variety of scholarly literature, including fourteen research studies (See Appendix).

Next, I intrinsically analyzed the data in the categories using "a within-study literature analysis" (Onwuegbuzie, Leech \& Collins, 2012, p. 5) by reading across all categories to identify subcategories connecting imagination and literacy. Five main subcategories were identified through analysis of data: relationship to comprehension, engagement with the textual world, connections across genres, connections to self and others, and instructional implications.

\section{Data Analysis}

Through reading across the subcategories, again using "a within-study literature analysis" (Onwuegbuzie, Leech \& Collins, 2012, p. 5), I identified four ways readers use imagination. I also documented benefits of instructing readers to use imagination. First, readers use imagination to comprehend text. Second, readers use imagination to engage in the world depicted through the text. Third, readers use imagination to make sense of both narrative and expository texts. Fourth, readers use imagination to learn about self and others. Finally, readers benefit from instruction regarding the use of imagination to enhance reading. In the following pages, the research identifying each of the five uses is explained and connected to classroom contexts.

Findings: Connections between Imagination and Literacy Instruction and Learning

Readers Use Imagination to Comprehend Text

Research indicates that readers use imagination to enhance understanding (Gambrell \& Bales, 1986; Langer, 1990; Maine, 2013; McTigue, 2010; Romano, 2006; Roser et al., 2007) . Imagination aids readers as they connect text to pictures or text to text or text to real life (McTigue, Romano, Maine). 
Langer uses the term envisionment to encapsulate the sense-making that may exceed comprehension. Langer (1990) observed adolescent students developing personalized textual worlds. She determined each reader relied on his/her previous knowledge, assumptions and imaginings to make meaning at any one point in a text. Langer collected 216 protocols from thirtysix students, equally divided between two groups, one group in grade seven and one group in grade eleven (U.S.). Think-alouds were recorded as each student read and responded to short stories and poems as well as science and social studies selections. Qualitative analysis led Langer to determine readers developed four recursive stances as they acquired comprehension of the text. She labeled the stances "(1) being out and stepping into an envisionment, (2) being in and moving through an envisionment, (3) stepping back and rethinking what one knows, and (4) stepping out and objectifying the experience" (p. 229). Langer found the readers' stances were fluid, changing across time. According to Langer, final reading comprehension combined thoughts related and unrelated to the text. Imagination and interpretation added to comprehension, "an evolving whole, which itself is subject to change well after the pages have been removed from sight" (p. 232).

Listening comprehension involves imagination and contributes to reading engagement and comprehension (McTigue, 2010; Romano, 2006; Roser et al., 2007). Romano states that good readers learn to extend their thinking, to "imagine pictures beyond the words of a text" (p. 376). In Romano's essay, he recounts a story he remembers vividly from an experience as a young child. When, as an adult, Romano sought the remembered-text, he was disappointed to find that his memory of a teacher's read-aloud differed dramatically from the actual morality tale. Nevertheless, Romano realizes that his imaginative rendition of that tale and other tales added interest and engagement that drew him to practice reading throughout his lifetime.

Maine (2013) discusses the need to extend discussions of twenty-first century comprehension skills to include written, visual and multi-modal texts. Maine conducted a qualitative study with eight children in primary grades to determine how the children's comprehension developed as they interacted with each other and a variety of texts. She found that, in every interaction, the children used imagination to "support their understanding" (p. 152) of the texts they read, viewed, and discussed. She found the young children's meaning-making exceeded "prescribed skills" (p. 154), leading to understanding of characters' motives.

On a cautionary note, some researchers report processes involved with imagination interfere as early readers engage in decoding (Gambrell, 1982; McTigue, 2010; Sadoski \& Paivio, 2013). Gambrell declared reading comprehension was enhanced for readers in third grade who were encouraged to predict during readings but not for readers in first grade who were encouraged to predict. However, no negative effects were reported for the beginning readers. Sadoski (1985) also stated early readers experienced more decoding errors when asked to visualize story events. On the other hand, the same researchers who report interference related to decoding processes join researchers who acknowledge imagination contributes important elements to comprehension (Gambrell, 1982; Gambrell \& Jawitz, 1993; Langer, 1990; Maine, 2013; McTigue, 2010; Sadoski \& Paivio, 2013; Spencer, 2002). Gambrell \& Jawitz cite four previous research studies as they declare, the "meaning of a text is not inherent in the print on the page but is the result of constructive processes that the reader brings to bear on the message" (p. 266). As a result, Gambrell \& Jawitz emphasize the need for readers to engage imagination in order to interact with the text.

If reading were simply decoding, the potential distractions for young readers would be more concerning. However, multiple researchers, including those who verified imagination may interfere with decoding, report that the potential distractions are part of the meaning-making involved in the reading process (Langer, 1990). The research culled through this content analysis 
seems to show that reader response (Rosenblatt, 1978), envisioning and reacting to the text, is an imaginative process that aids comprehension. Mental imagery (Paivio, 1971) and oral literacy experiences (Dyson \& Genishi, 2013) feed the reader's response so that imagination may usher readers into new worlds through stories, "resulting in greater depth of processing and increased story comprehension and recall” (Gambrell \& Jawitz, 1993, p. 272).

Readers Use Imagination to Engage in the World Depicted through the Text

The second use of imagination identified through this content analysis adds identity (Gee, 2004) to connections between reader response and imagination. A quarter-century ago, Gambrell \& Jawitz (1993) hypothesized that "imagery may facilitate the reader's entry into the secondary world of the story" (p. 272). More recently, research conducted with beginning readers (Roser et al., 2007) and high school students (Peskin et al., 2010) found that students imaginatively entered the world of the story through listening or symbolic interpretation. Taken together, these studies indicate that if readers are entering the story imaginatively, either through imagery, listening, or symbolic interpretation, the readers are identifying themselves as part of the story. Identity (Gee, 2004) is impacted as students view themselves as readers who can enter the story.

Gambrell \& Jawitz (1993) worked with 120 students in fourth-grade classrooms in three public schools in Florida. Groups of five to seven students met with a researcher to read a story, write about the story, and answer questions about the story. Time was standardized across all treatment groups, with children assigned to one of four groups, with number four being the control group. Procedures in each group were designed to allow the researchers to meet the four following goals:

1) to study the "effects of readers' combined use of imagery and illustrations" (p. 268),

2) to determine the use of imagery without illustrations,

3) to examine the impact of focusing on illustrations,

4) to learn the effects of students reading a non-illustrated text and being told "to try to remember the story" (p. 268).

The group focusing on imagery and illustrations outperformed all other groups, with $70 \%$ of the children writing complete stories. The imagery-only group wrote the second highest number of complete stories (58\%). The groups not invited to engage imagination wrote fewer complete stories (40\% in the illustrations-only group, 33\% in the control group). Gambrell and Jawitz (1993) concluded that introducing a strategy of imagery-production to children was a valuable tool, aiding understanding and connection to the story.

Peskin, et al. (2010) present one study that illustrates ways high school students in Canada responded to instruction that led the students to engage deeply in the textual world of poetry. A teacher of high school English and two academics in the field of cognitive psychology designed research with the assumption that poets and writers provide stimuli for readers' imaginations. The researchers designed lessons to teach students to use imagination to symbolically interpret poetry. Two classes, taught by the teacher-researcher, were shown through statistical analyses to be equivalent in earned grades, written responses, and verbal reasoning. For the purpose of the research, the classes were randomly assigned so one class received three types of symbolism lessons while the other class served as a control group. The control group received the instruction delivered as normally taught by the teacher-researcher: "small-group and large-group discussions of various poems, examining general aesthetic aspects of poetic appreciation: allusions, repetitions, arrangement of ideas, word choice, sound textures in words, rhyme, and rhythm, and so on" (p. 500). The students also wrote and discussed their own original poems. However, the 
control group did not receive the three types of symbolism lessons that the teacher-researcher presented to the symbolism group.

To measure possible differences after the differing instruction, students' responses to poems were coded for "showing some evidence of symbolic interpretation or not showing any evidence of such interpretation" (Peskin, et al., 2010, p. 505). The researchers found the control group's responses were more literal, while the symbolism group responded more "imaginatively, finding fresh meanings related to various contexts" (p. 506). The researchers determined that, as a result of the symbolism lessons, students in the symbolism group interpreted symbols in ways that "broadened their understanding of imaginative connections" (p. 503). In response to specific lessons, the researchers determined students used their imaginations to engage more fully in the world of the texts.

A third study highlights ways imaginative understanding of text can begin as young readers listen to read-alouds. Roser et al. (2007) stated "Understanding a character deeply (particularly for young readers) may mean stepping imaginatively into a role” (p. 554). In a six-week study, three university researchers observed as a first-grade teacher read aloud and invited students to interact with characters through multi-sensory experiences. The students were encouraged to feel and engage vicariously in characters' experiences. During the readings, the teacher invited students to tiptoe or create sounds or offer food as the character did. The students' imaginations were engaged as they dive-rolled like one character or voiced sounds made by another character.

From listening in grade one to producing mental images in grade four to symbolic interpretation of poetry in older grades, research shows students can enter textual worlds imaginatively, deepening connections and understandings (Gambrell \& Jawitz, 1993; Peskin et al., 2010; Roser, et al. 2007). Maine (2013) and Langer (1990) showed the same for primary students and middle school and high school students, respectively. Langer's work extends across genres, reiterating that imagination is as essential to scientific reasoning as it is to literary understanding.

Readers Use Imagination to Make Sense of Both Narrative and Expository Texts

In the section of the analysis, the use of imagination across genres is discussed (Brozo \& Flynt, 2007; Douville \& Algozzine, 2004; Langer, 1990; NEA, 2007; Romano, 2006). Beyond the types of envisionment explained in the first section of these findings, Langer found that genre affected ways students used imagination. While reading literary materials, the students in Langer's (1990) study explored a range of possibilities as they read. On the other hand, while reading informative materials, Langer's students kept in mind "a point of reference" (p. 229). Brozo \& Flynt (2007) expressed the need for teachers to develop abilities to engage students' imaginations when the students are reading nonfiction.

The value of teaching students to engage imagination in multiple genres through multisensory images was reported by Douville and Algozzine (2004). Douville's studies incorporated both narrative and expository texts. First, with students in fifth grade, Douville modeled, then provided four weeks of instruction using processes she dubbed the Sensory Activation Model( SAM) strategy. In a similar study, Douville \& Boone (2003) provided six days of instruction, again beginning with modeling, for students in second grade. For four days, students experienced using the five sense modalities (visual, auditory, gustatory, olfactory, tactile/emotional) in writing and reading activities. On Day Five, students were introduced to SAM, a figure who possessed extraordinary senses and "could simply read about sensory experiences and be able to taste, smell, hear, feel, and see what happened as if he were actually in the story!" (2004, p. 37). On Days Five and Six the students in second grade were encouraged to take SAM with them while working independently on reading and writing activities. Long-range, 
the teachers reported that students used the strategy, without prompting, across the curriculum. Measurable effects of using the multi-sensory imaging process included vocabulary growth, new understandings of abstract mathematical concepts, and deep levels of engagement with texts.

Other writers refer to the power of imagination across content areas. A research report from the National Endowment for the Arts (2007) connected positively imagination, analytical skills, arts and sciences. Romano (2006) connected both narrative and fiction in his comments recounted in the first finding of this article. From these studies, imagination appears key to all readers as they seek to understand all texts. Researchers might repeat the same processes to determine if activating multisensory imaging processes enhances understanding of fiction and nonfiction in additional classrooms.

\section{Readers Use Imagination to Learn about Self and Others}

In addition to amplifying understanding of text genres, the use of imagination seems to help readers gain greater understanding of people. Empathy, respect, and passion have been observed as students are encouraged to engage imagination in literate activities(Miller, 1977; Schofield \& Rogers, 2004). Miller recounts numerous ways three-year-old children verbally use "unreal" or imaginary events to make sense of reality. Hannaford (2012), as a result of research with eight- and nine- year-old children, describes imaginative play as "the work of children undertaking identity practice" (p. 31). Social imagination (Johnston, 1993; Lysaker \& Sedberry, 2015) and cultural imagination (Enciso \& Shanahan, 1993; Spencer, 2002) appear as research terms across decades, showing researchers and practitioners have recognized ways literacy and imagination contribute to understanding of self and others.

Working with youth labeled at-risk in an alternative school setting, Schofield \& Rogers (2004) determined imagination was an essential element of instruction, providing students' understanding about themselves and their life situations. The teachers introduced autobiography and biography as devices to motivate the students to engage in literacy practices. Imagination offered a strategic tool as the students were encouraged to combine their own stories with multigenre texts they read and viewed. The researchers found the youth developed positive literacy identities by drawing on their own "biographies, imaginations, and multiple and hybrid identities" (p. 247). Experimental text forms and new technologies along with pedagogical practices that prized imagination yielded "respect, passion, and playfulness" (p. 247). Thus, the youth incorporated cultural imagination by employing "everyday images, languages, places, and times to inform their sense of identity" (Enciso \& Shanahan, 1993, p. 336).

Social imagination has been identified a bit differently. Johnston (1993) labeled social imagination "the ability to imagine what it is like to be someone else" (p. 428). Lysaker \& Sedberry (2015) attempted to measure children's social imagination, studying the reactions and responses of two boys in fourth grade. The researchers provided picture books in which the text was not explicit, allowing room for readers' interpretations. The illustrations in these texts included "characters whose expressions are blurred, hidden or otherwise unclear, inviting readers to imagine their inner worlds" (p. 107). Lysaker \& Sedberry found the images did encourage the boys' imaginations in ways that promoted empathy and understanding of others' possible viewpoints. Identity formation and empathy are not easily measured through standardized tests. Still, in western society, both identity formation and empathy are generally regarded as positive social and cultural traits that positively impact students' literacy practices.

Readers Benefit from Instruction Regarding the Use of Imagination to Enhance Reading

Finally, the research shows that students who do not intuitively activate imagination can learn to do so as they speak, read, and write (Enciso \& Shanahan, 1993; Gambrell, 1982; McTigue, 
2010; Serafini \& Moses, 2014). Readers benefit most from using multi-sensory imaginative strategies (Douville \& Algozzine, 2004; Roser et al., 2007; Schofield \& Rogers, 2004). Douville \& Algozzine acknowledge that "many students tacitly apply mental imagery to learning tasks, but other students must be taught to do so" (p. 39). Fortunately, the literature offers numerous ways to teach students to engage imagination. Methods incorporated into five studies are described in this section.

Beginning with oral storytelling and progressing to reading instruction, McTigue (2010) instructed students in grade two to imagine story happenings through visualization. In one early lesson, the oral story was interrupted by students' questions regarding the color of a monkey in the tale. McTigue suggested the monkey could be any color, but her students had different ideas; at first a few students insisted on one color or another. McTigue reported, "Although the actual color of the monkey is insignificant, their interest in that question represented a critical point in my students' metacognition about imagery" (p. 55). Together the teacher and students developed vocabulary and methods to lead students to produce mental images of story elements that were not already defined in a story.

Gambrell (1982) used a visual prompt for children in first and third grades, asking them to "make pictures in your head about what you read to help you remember" (np). She concluded that students' interactions with text benefitted from this "induced mental imagery" (np). Her findings at that time indicated the older children gained more in terms of comprehension from mental imagery than did the younger children in the sample. Nevertheless, Gambrell reported positive understandings developed for the younger children as well.

As described in the second section of findings in this article, Roser et al. (2007) invited children in grade one to engage in oral readings imaginatively. Multi-sensory prompts were provided such as "Just imagine. Here is this loud, loud dragon roar. Just everyone do it together..." (p. 554). A novel was read over a six-week period, allowing the teacher and students to engage in multiple demonstrations and practices. Through students' response journals, the researchers found the students used the multi-sensory experiences to engage imagination in order to deepen their understanding of characters, plots, and themes in complex text.

Enciso \& Shanahan (1993) used manipulative cutouts to allow children in fifth-grade to show where they saw themselves in the textual story world. Additional instructional methods employed by Enciso included "improvised drama, visual art, dance, and music" (p. 337) to encourage children to engage imagination. The researchers reported that, through such activities, the children learned from texts and about culture and their own identities.

In a study described in the fourth section of these findings, Schofield \& Rogers (2004) developed multiple means for giving adolescents license to bring imagination into their schoolwork. Youth were given freedom of choice across multiple genres and media. Dialogue and playfulness were encouraged along with verbal and visual forms of imagination. Guidelines provided for portfolio evaluation included "criteria that emphasize the genesis of the projects, including biographical, imaginative sources of storytelling" (p. 244). The teacher-researchers and the young people acknowledged important literacy learning and engagement as a result of the methods used to integrate curriculum and the students' lives.

Additional practical statements from researchers include the following:

- modeling is important but students "must be taught how to self-construct their own personally relevant images in order to have control over the imaging process" (Douville \& Algozzine, 2004, p. 36). 
- lead students to imagine "why a particular writer would use particular words, stylistic devices, or formats" (Johnston, 1993, p. 429).

- unconventional methods, such as telling stories in a darkened classroom, tend to accentuate "students' attention and questions on their internal images" (McTigue, 2010, p. 53).

Finally, Brozo \& Flynt (2007) call on teachers to recognize the essential nature of developing our own knowledge and abilities to lead students to apply imagination in order to thoroughly understand content texts and language across all disciplines.

The studies presented in this analysis provide a starting place for teachers who want to add or enhance imaginative connections in their own classrooms. The analysis also provides background for researchers who want to investigate additional possibilities.

\section{Implications /Conclusions}

In the last twenty-five years, researchers have identified specific strategies, mentioned in the Findings section, that teachers can use to link imagination and literacy. These findings suggest three implications: 1. Multi-sensory prompts deepen literacy engagement. 2. Students at all levels can be instructed to engage imagination in order to deepen understanding as they read. Across all ages, multi-sensory prompts have been found more effective than relying only on visualization (Roser et al., 2007; Schofield \& Rogers, 2004). In addition, abstract, loosely defined prompts have been found more effective than highly realistic prompts (King, 2007). These findings challenge the idea that specific prompts and explicit instruction deliver the most effective methods for incorporating imagination in literacy.

Furthermore, even though decoding processes may be slowed temporarily by directing beginning readers to engage imagination as they read (Gambrell, 1982), the benefits to overall comprehension and engagement appear to outweigh any concerns. The research analyzed here suggests the importance of recognizing that reading includes many aspects in addition to decoding. And making meaning involves connecting words on a page to pictures, sounds, smells, tastes, and touches elicited by the text.

Researchers can certainly build on the findings of this analysis to determine best practices for combining concrete and abstract methods in literacy instruction. While children today can find many outlets for imagination through media and digital devices, we teachers need to remember that we've known for forty years that students can learn to activate imagination in order to understand written text (Pressley, 1976). Research and dissemination of known strategies need to be reactivated (Gambrell \& Jawitz, 1993) so teachers can learn methods of instruction to deepen understanding and engagement. However, as stated in the Significance section of this analysis, research connecting imagination and literacy were more prevalent in the 1980s and 1990s than recently. So, the literature analyzed for this article may indicate that interest has waned regarding research showing classroom connections between imagination and literacy. Or this analysis may show that this important research has not been fully conceptualized. Perhaps in some instances, terms such as visualization have been substituted for the term imagination in recent research. Nevertheless, this analysis shows imagination far exceeds visualization or any one approach. Imagination is a multi-faceted concept that deserves a robust research base so educators may confidently apply practices that enhance reading comprehension and engagement. 


\section{Limitations}

This content analysis gathered data from three journals. Other journals might include articles related to imagination and literacy instruction. As explained in the Methods section, snowballing deepened the sample to a limited extent. Still, a systematic analysis of other journals will undoubtedly find more examples of educators using imagination in literacy instruction. Therefore, additional research is recommended to determine if more instructional strategies have already been identified.

Further, we literacy educators may have under-utilized the term imagination. As a result, even in the journals reviewed, this content analysis may not have discovered all classroom uses of imagination connected with literacy instruction. Other research could analyze journal content more broadly, seeking additional terms related to imagination or reports of classroom actions that utilize imagination without naming it.

\section{Final Thoughts}

Authors have tended to use the terms imagine, imagination, imaginatively as commonplaces. We are all human; we all imagine. So we all conjecture about imagination in literacy classrooms. This article is a call to contemplate potentially important considerations for research leading to practice. Researchers cited in this content analysis have investigated multiple methods for teaching students from preschool through high school to engage imagination. Taken together, the research analyzed presents multiple ways imagination seems to enhance literacy instruction. According to this content analysis, discourse regarding imagination and literacy was more prevalent in earlier years. Thus the analysis also establishes a need for continued research regarding practices related to the effects of imagination on literacy learning. Perhaps researchers need to further conceptualize the term imagination as it relates to literacy and literacy instruction. As the term imagination is utilized more purposefully, researchers and educators can question and verify earlier results, offering educators practices to use with confidence.

\section{References}

Anderson, E. B. (2013). Stop, look, listen: Contemplative teaching and learning. Christian Education Journal, 10(2), p. 392-406.

Brill, F. (2004). Thinking outside the box: Imagination and empathy beyond story writing. Literacy, 38(2), p. 83-89

Brozo, W. G., \& Flynt, E. S. (2007). Content literacy: Fundamental toolkit elements. Reading Teacher, 61(2), 192-194. doi:10.1598/RT.61.2.9

Clay, M. M. (1991). Introducing a new storybook to young readers. Reading Teacher, 45(4), 264-273.

Douville, P., \& Algozzine, B. (2004). Use mental imagery across the curriculum. Preventing School Failure, 49(1), 36-39.

Douville, P., \& Boone, E. (2003). Paper presented at the North Carolina Reading Association 34th Annual Conference: Scaffolding mental imagery with elementary readers. Greensboro, NC.

Dyson, A. H. \& Genishi, C. (2013). Social talk and imaginative play: Curricular basics for young children's language and literacy. Chapter 6, pp. 164 - 181. In D. E. Alvermann, N. J. Unrau, \& R. B. Ruddell, (Eds.). Theoretical Models and Processes of Reading (6th Edition). Newark, DE, USA: International Reading Association. 
Emig, J. (1971). The composing processes of twelfth-graders (Research Report No. 13). Urbana, IL: National Council of Teachers of English.

Enciso, P., \& Shanahan, T. (1993). Integrating 'cultural imagination'. Reading Teacher, 47(4), 336-337.

Gambrell, L.B. (1982). Induced mental imagery and the text prediction performance of first and third graders. In J.A. Niles \& L.A. Harris (Eds.), New inquiries in reading research and instruction (31st yearbook of the National Reading Conference, pp. 131-135). Rochester, NY: National Reading Conference.

Gambrell, L.B. \& Bales, R. (1986). Mental imagery and the comprehension-monitoring performance of fourth- and fifth-grade poor readers. Reading Research Quarterly, 21, 454-464.

Gambrell, L.B., \& Jawitz, P.B. (1993). Mental imagery, text iliustrations, and children's story comprehension and recall. Reading Research Quarterly, 28, 265-276.

Gee, J. P. (2004). Situated language and learning:A critique of traditional schooling. New York: Routledge.

Hall, C. \& Jones, S. (2016). Making sense in the city: Dolly Parton, early reading and educational policy-making. Literacy, 50(1), 40-48.

Hall, M. P., O'Hare, A., Santavicca, N., Jones, L. F. (2015). Journal Educational Innovation / Revista Innovación Educativa, 15(67), 49-59.

Hannaford, J. (2012). Imaginative interaction with Internet games:For children and teachers. Literacy, 46(1), 25-32.

Hoffman, J. V., Wilson, M. B., Martinez, R. A. \& Sailors, M. (2011). Content analysis:The past, present, and future. In N. K. Duke \& M. H. Mallette (Eds.), Literacy Research Methodologies ( $2^{\text {nd }}$ ed.) (pp. 28-49).

Hruby, G. G., \& Goswami, U. (2011). Neuroscience and reading: A review for reading education researchers. Reading Research Quarterly, 46(2), 156-172.

Hsieh, H. \& Shannon, S. E. (2005). Three approaches to qualitative content analysis. Qualitative Health Research 15(9), 1277-1288. DOI: 10.1177/1049732305276687

International Reading Association. (2009). New Literacies and $21^{\text {st }}$ Century Technologies: A Position Statement of the International Reading Association. http://www.reading.org

Ivey, G. \& Johnston, P. (2013). Engagement with young adult literature:Outcomes and processes. Reading Research Quarterly, 48(3), 255-275. doi:10.1002/rrq.46

Johnston, P. H. (1993). Assessment and literate 'development'. Reading Teacher 46(5), 428.

King, N. (2007). Developing imagination, creativity, and literacy through collaborative storymaking:A way of knowing. Harvard Educational Review, 77(2), 204-227.

Langer. J. A. (1990), The purpose of understanding:Reading for informative purposes. Research in the Teaching of English, 24(3), 229-260.

Layne, S. (2009). Igniting a passion for reading:Successful strategies for building lifetime readers. Stenhouse.

Lysaker, J. \& Sedberry, T. (2015). Reading difference:Picture book retellings as contexts for exploring personal meanings of race and culture. Literacy, 49(2), 105-111.

Maine, F. (2013). How children talk together to make meaning from texts:A dialogic perspective on reading comprehension strategies. Literacy, 47(3), 150-156.

McCarthey, S. J.; Moje, E. B. (2002). Identity matters. Reading Research Quarterly, 37(2), 228238. DOI: $10.1598 / R R Q .37 .2 .6$ 
McTigue, E. M. (2010). Teaching Young Readers Imagery in Storytelling: What Color Is the Monkey?. Reading Teacher, 64(1), 53-56. doi:10.1598/RT.64.1.6

Miller, G. A. (1977). Spontaneous apprentices: Children and language. NY: Seabury Press.

Moje, E.B. \& Luke, A. (2009). Literacy and identity:Examining the metaphors in history and contemporary research. Reading Research Quarterly, 44(4), 415-437. doi.org/10.1598/RRQ.44.4.7

National Endowment for the Arts (2007). To read or not to read. Research Report \#47. https://www.arts.gov/file/2667. Accessed 3/28/2016.

Nystrand, S. (2006). Research on the role of classroom discourse as it affects reading comprehension. Research in the Teaching of English, 40(4), 392-412.

Onwuegbuzie, A. J.; Leech, N. L. \& Collins, K. M. T. (2012). Qualitative Analysis Techniques for the Review of the Literature. The Qualitative Report, 17, Article 56, 1-28. http://www.nova.edu/ssss/QR/QR17/onwuegbuzie.pdf

Paivio, M. (1971). Imagery and verbal processes. New York: Holt, Rinehart, Winston.

Pelttari, C. A., \& Marchetti, J. E. (2014), Presentation at International Reading Association 59th Annual Conference, Reading the Teachable Moment: Connections Proficient Readers Make When Texts Include Character-Writers. New Orleans, LA.

Peskin, J., Allen, G., \& Wells-Jopling, R. (2010). "The Educated Imagination": Applying Instructional Research to the Teaching of Symbolic Interpretation of Poetry. Journal of Adolescent \& Adult Literacy, 53(6), 498-507.

Pressley, G.M. (1977). Mental imagery helps eight year olds remember what they read. Journal of Educational Psychology, 68, 355-359.

Romano, T. (2006). Picturing meaning. Journal of Adolescent \& Adult Literacy, 49(5), 374-377. doi:10.1598/JAAL.49.5.1

Rosenblatt, L. M. (1978). The reader, the text, the poem. Carbondale, IL: Southern Illinois University Press.

Rosenblatt, L. M. (1938/1995). Literature as exploration. New York: Modern Language Association.

Roser, N., Martinez, M., Fuhrken, C., \& Mcdonnold, K. (2007). Characters as guides to meaning. Reading Teacher, 60(6), 548-559. doi:10.1598/RT.60.6.5

Routman, R. (2003). Reading essentials. Portsmouth, NH: Heinemann.

Sadoski, M. (1985). The natural use of imagery in story comprehension and recall: Replication and extension. Reading Research Quarterly, 20, 658-667.

Sadoski, M. \& Paivio, A. (2013). A dual coding theoretical model of reading. Chapter 34, pp. 886 - 992. In D. E. Alvermann, N. J. Unrau, \& R. B. Ruddell, (Eds.). Theoretical Models and Processes of Reading (6th Edition). Newark, DE, USA: International Reading Association.

Schofield, A., \& Rogers, T. (2004). At play in fields of ideas. Journal of Adolescent \& Adult Literacy, 48(3), 238-248. doi:10.1598/JAAL.48.3.5

Serafini, F., \& Moses, L. (2014). The roles of children's literature in the primary grades. Reading Teacher, 67(6), 465-468. doi:10.1002/trtr.1236

Spencer, M. M. (2002, July 29). What more needs saying about imagination? Address at the International Reading Association World Congress, Edinburgh, Scotland. Reprinted in (2003) The Reading Teacher, 57(1), 105-111.

Stevenson, R. L. (1885) A child's garden of verses. www.poemsforchildren.org

Walsh, C. S. (2007). Creativity as capital in the literacy classroom: youth as multimodal designers. Literacy, 41(2), $79-85$. 
Wilhelm, J. \& Smith, M. (2014). Reading unbound:Why kids need to read what they want - and why we should let them. Scholastic.

Wood, K. D., \& Endres, C. (2004). Motivating student interest with the Imagine, Elaborate, Predict, and Confirm (IEPC) strategy. Reading Teacher, 58(4), 346-357.

doi:10.1598/RT.58.4.4

\section{Appendix}

Studies are listed by author, organized by date of publication. The second column, Source, names the publication and whether the publication was one of the three target journals or was identified through snowballing as a result of citations in a target journal. The three final columns briefly list the details regarding the participants (sample), procedures, and findings.

\begin{tabular}{|c|c|c|c|c|}
\hline Authors & Source & Sample studied & Procedures & Findings \\
\hline $\begin{array}{l}\text { Gambrell } \\
(1982)\end{array}$ & $\begin{array}{l}31 \text { st } \\
\text { yearbook of } \\
\text { the National } \\
\text { Reading } \\
\text { Conference/ } \\
\text { Snowballing }\end{array}$ & $\begin{array}{l}291^{\text {st }} \text { grade, } 293^{\text {rd }} \\
\text { grade, randomly } \\
\text { assigned. }\end{array}$ & $\begin{array}{l}\text { Experimental group told to } \\
\text { "make pictures in your head } \\
\text { about what you read to help } \\
\text { you remember" (np) } \\
\text { Control group: "Think } \\
\text { about what you read to help } \\
\text { you remember" (np). }\end{array}$ & $\begin{array}{l}\text { "These findings strongly } \\
\text { suggest that reader-text } \\
\text { interaction is enhanced by } \\
\text { induced mental imagery" } \\
\text { (np). }\end{array}$ \\
\hline $\begin{array}{l}\text { Gambrell \& } \\
\text { Bales } \\
(1986) .\end{array}$ & $\begin{array}{l}\text { Reading } \\
\text { Research } \\
\text { Quarterly / } \\
\text { Snowballing }\end{array}$ & $\begin{array}{l}\text { "Sixty-two fourth- } \\
\text { grade and } 62 \text { fifth- } \\
\text { grade poor readers" } \\
\text { (p. 654). }\end{array}$ & $\begin{array}{l}\text { Experimental group } \\
\text { explicitly told: "One good } \\
\text { way to understand and } \\
\text { remember what you read is } \\
\text { to make pictures in your } \\
\text { mind. I want you to make } \\
\text { pictures in your mind to } \\
\text { help you understand and } \\
\text { remember what you read.' } \\
(\text { p. } 458) \text {. }\end{array}$ & $\begin{array}{l}\text { "mental imagery is a viable } \\
\text { strategy for less skilled } \\
\text { readers to enhance reading } \\
\text { comprehension and is } \\
\text { deserving of attention in } \\
\text { instructional methodology } \\
\text { texts as a specific } \\
\text { comprehension strategy" (p. } \\
462) \text {. }\end{array}$ \\
\hline $\begin{array}{l}\text { Langer. J. } \\
\text { A. (1990), }\end{array}$ & $\begin{array}{l}\text { Research in } \\
\text { the } \\
\text { Teaching of } \\
\text { English / } \\
\text { Snowballing }\end{array}$ & $\begin{array}{l}216 \text { protocols were } \\
\text { collected from } 36 \\
\text { students ( } 18 \text { seventh } \\
\text { graders and } 18 \\
\text { eleventh graders). }\end{array}$ & $\begin{array}{l}\text { "Over several weeks, each } \\
\text { student engaged in a series } \\
\text { of think-aloud sessions } \\
\text { during which each read two } \\
\text { short stories, two poems, } \\
\text { one science selection, and } \\
\text { one social studies selection" } \\
\text { (p.229). }\end{array}$ & $\begin{array}{l}\text { "Findings identify four } \\
\text { recursive stances readers } \\
\text { take in relation to the text, } \\
\text { with each adding a } \\
\text { somewhat different } \\
\text { dimension to the } \\
\text { understanding of the entire } \\
\text { piece" (p. 229). }\end{array}$ \\
\hline $\begin{array}{l}\text { Gambrell, } \\
\text { L.B., \& } \\
\text { Jawitz, P.B. } \\
\text { (1993). }\end{array}$ & $\begin{array}{l}\text { Reading } \\
\text { Research } \\
\text { Quarterly / } \\
\text { Snowballing }\end{array}$ & $\begin{array}{l}120 \text { fourth-grade } \\
\text { students in } 3 \text { Florida } \\
\text { public schools. }\end{array}$ & & $\begin{array}{l}\text { "some evidence that mental } \\
\text { imagery was more effective } \\
\text { than attending to } \\
\text { illustrations with respect to } \\
\text { reading comprehension } \\
\text { performance" (p. 271). }\end{array}$ \\
\hline $\begin{array}{l}\text { Enciso \& } \\
\text { Shanahan } \\
(1993)\end{array}$ & $\begin{array}{l}\text { The } \\
\text { Reading } \\
\text { Teacher / } \\
\text { Target } \\
\text { journal }\end{array}$ & $\begin{array}{l}\text { Students in grade } 5 \text {, } \\
\text { rural Ohio }\end{array}$ & $\begin{array}{l}\text { Asked students to create } \\
\text { cutouts picturing characters, } \\
\text { setting, self. Then asked } \\
\text { each student to read a } \\
\text { portion of the story and } \\
\text { place cutouts to represent } \\
\text { the student's view of the } \\
\text { story. }\end{array}$ & $\begin{array}{l}\text { Reported evidence of } \\
\text { students' ability "to use } \\
\text { images, sounds, movement, } \\
\text { and words" (p. 336) to } \\
\text { develop cultural } \\
\text { understanding and world } \\
\text { view. }\end{array}$ \\
\hline
\end{tabular}




\begin{tabular}{|c|c|c|c|c|}
\hline Brill (2004) & $\begin{array}{l}\text { Literacy / } \\
\text { Target } \\
\text { journal }\end{array}$ & $\begin{array}{l}33 \text { letters (written by } \\
18 \text { females, } 15 \text { males } \\
\text { from } 13 \text { schools in } \\
\text { England) from a } \\
\text { sample of } 900 \\
\text { assessment-related } \\
\text { tasks. }\end{array}$ & $\begin{array}{l}\text { Letters were produced by } \\
\text { students who chose one of } 4 \\
\text { different writing tasks. } \\
\text { Students had } 15 \text { minutes to } \\
\text { plan, } 45 \text { minutes to write. }\end{array}$ & $\begin{array}{l}\text { Imagination was evident in } \\
\text { all letters. Imagination was } \\
\text { used to develop empathy } \\
\text { and relationship with the } \\
\text { audience. Imagination } \\
\text { contributed to reasoning } \\
\text { skills. }\end{array}$ \\
\hline $\begin{array}{l}\text { Douville \& } \\
\text { Algozzine } \\
(2004) .\end{array}$ & $\begin{array}{l}\text { Preventing } \\
\text { School } \\
\text { Failure / } \\
\text { Snowballing }\end{array}$ & $\begin{array}{l}\text { Report of two studies } \\
\text { (Douville, } 1998 \text { with } \\
\text { students in grade 5; } \\
\text { Douville \& Boone, } \\
2003 \text { with students in } \\
\text { grade 2). }\end{array}$ & $\begin{array}{l}\text { "fifth-graders received } 4 \\
\text { weeks of explicit } \\
\text { instruction in the SAM } \\
\text { [Sensory Activation Model, } \\
\text { Douville, 1998] strategy; } \\
\text { teachers first modeled their } \\
\text { own use of multisensory / } \\
\text { imagery with text, next } \\
\text { guided the students in } \\
\text { constructing and sharing } \\
\text { images } \\
\text { within a large group } \\
\text { instructional setting, and } \\
\text { finally released students to } \\
\text { construct } \\
\text { multi-sensory images } \\
\text { independently in reading } \\
\text { both narrative and } \\
\text { expository texts" (p. 36-7). }\end{array}$ & $\begin{array}{l}\text { "students spontaneously } \\
\text { applied the SAM strategy to } \\
\text { reading and writing } \\
\text { activities after the initial 6- } \\
\text { day training period without } \\
\text { being specifically cued to do } \\
\text { so; many of the students } \\
\text { also independently } \\
\text { transferred the strategy to } \\
\text { other } \\
\text { content areas as well (e.g., } \\
\text { mathematics)" (p. 37). }\end{array}$ \\
\hline $\begin{array}{l}\text { Schofield } \\
\text { \& Rogers } \\
(2004)\end{array}$ & $\begin{array}{l}\text { Journal of } \\
\text { Adolescent } \\
\& \text { Adult } \\
\text { Literacy / } \\
\text { Target } \\
\text { journal }\end{array}$ & $\begin{array}{l}\text { "Students designated } \\
\text { at risk and enrolled } \\
\text { in a youth literacy } \\
\text { program" (p. 240) in } \\
\text { a public school in } \\
\text { British Columbia, } \\
\text { Canada. }\end{array}$ & $\begin{array}{l}\text { Analyzed field notes, } \\
\text { observations, student work, } \\
\text { teacher and researcher } \\
\text { journals, and transcribed } \\
\text { student interviews. } \\
\text { "Guidelines [for portfolio } \\
\text { evaluation] included criteria } \\
\text { that emphasize the genesis } \\
\text { of the projects, including } \\
\text { biographical, imaginative } \\
\text { sources of storytelling" (p. } \\
\text { 244). }\end{array}$ & $\begin{array}{l}\text { Researchers reported } \\
\text { students were motivated "to } \\
\text { think and imagine across } \\
\text { disciplines" (p. 241). } \\
\text { Researchers also noted "a } \\
\text { playfulness that encourages } \\
\text { students' imaginations" (p. } \\
\text { 241) and connections to all } \\
\text { aspects of their classroom. }\end{array}$ \\
\hline $\begin{array}{l}\text { Walsh } \\
(2007)\end{array}$ & $\begin{array}{l}\text { Literacy / } \\
\text { Target } \\
\text { journal }\end{array}$ & $\begin{array}{l}\text { Fifty- eight students } \\
\text { in two humanities } \\
\text { classes of "12- and } \\
13 \text {-year-old first and } \\
\text { second-generation } \\
\text { Chinese immigrant } \\
\text { students" (p. 79), in } \\
\text { New York City, } \\
\text { Chinatown. }\end{array}$ & $\begin{array}{l}\text { Analyzed websites } \\
\text { produced by seven } \\
\text { students: two by students I } \\
\text { call Mei and Ling, on the } \\
\text { Dust Bowl Migration and } \\
\text { one by a group of five } \\
\text { students (1 male, } 4 \text { females) } \\
\text { on reading migration } \\
\text { through the arts. The group } \\
\text { website was entered into } \\
\text { an out-of-school website } \\
\text { design competition, while } \\
\text { Mei's and Ling's were } \\
\text { class-assigned work from } \\
\text { their }\end{array}$ & $\begin{array}{l}\text { Students' literacy is } \\
\text { impacted when allowed to } \\
\text { bring out-of-school } \\
\text { knowledge, experiences, } \\
\text { and imagination to school } \\
\text { projects. Teachers need to } \\
\text { recognize the value of } \\
\text { inviting students to } \\
\text { participate in class through } \\
\text { student-designed } \\
\text { multimedia to aid students' } \\
\text { learning of "more traditional } \\
\text { school literacies" (84). }\end{array}$ \\
\hline
\end{tabular}




\begin{tabular}{|c|c|c|c|c|}
\hline & & & online portfolios. & \\
\hline $\begin{array}{l}\text { Roser, } \\
\text { Martinez, } \\
\text { Fuhrken \& } \\
\text { Mcdonnold } \\
\text { (2007). }\end{array}$ & $\begin{array}{l}\text { The } \\
\text { Reading } \\
\text { Teacher / } \\
\text { Target } \\
\text { journal }\end{array}$ & $\begin{array}{l}\text { The teacher, reading } \\
\text { aloud from a } \\
\text { complex novel in } \\
\text { one first- grade } \\
\text { classroom. }\end{array}$ & $\begin{array}{l}\text { Three university researchers } \\
\text { observed, recorded, and } \\
\text { took notes of every read- } \\
\text { aloud during a six-week } \\
\text { period. The researchers } \\
\text { analyzed the students' } \\
\text { response journals as well as } \\
\text { transcripts of classroom } \\
\text { discussions. They } \\
\text { "identified and coded each } \\
\text { of Kathleen's speech turns } \\
\text { that appeared intentional for } \\
\text { supporting meaning } \\
\text { making" and "noted the } \\
\text { ways in which talk about } \\
\text { character seemed central to } \\
\text { Kathleen's support, and } \\
\text { how her students were } \\
\text { drawn into and sustained by } \\
\text { the story when Kathleen } \\
\text { highlighted characters for } \\
\text { consideration" (553). }\end{array}$ & $\begin{array}{l}\text { Six instructional features } \\
\text { were found important as } \\
\text { students used characters to } \\
\text { make sense of the story. } \\
\text { One of the six features is } \\
\text { listed as "inviting } \\
\text { participation in the story - } \\
\text { dramatically, visually, and } \\
\text { imaginatively" (p. 554). }\end{array}$ \\
\hline $\begin{array}{l}\text { Peskin, } \\
\text { Allen \& } \\
\text { Wells- } \\
\text { Jopling, } \\
(2010)\end{array}$ & $\begin{array}{l}\text { Journal of } \\
\text { Adolescent } \\
\& \text { Adult } \\
\text { Literacy / } \\
\text { Target } \\
\text { journal }\end{array}$ & $\begin{array}{l}\text { Tested lessons with } \\
\text { two groups of 14- to } \\
\text { 15-year-olds (taught } \\
\text { by teacher- } \\
\text { collaborator) in } \\
\text { classes determined to } \\
\text { be equivalent on } 3 \\
\text { measures. Classes } \\
\text { randomly assigned } \\
\text { as "symbolism" or } \\
\text { control group. }\end{array}$ & $\begin{array}{l}\text { The symbolism group } \\
\text { received three scaffolds } \\
\text { during instruction. The } \\
\text { control group did not } \\
\text { receive instructional } \\
\text { scaffolds related to } \\
\text { symbolism. } \\
\text { "Students' interpretations of } \\
\text { the poem were then coded } \\
\text { as either showing some } \\
\text { evidence of symbolic } \\
\text { interpretation or not } \\
\text { showing any evidence of } \\
\text { such interpretation" (p. } \\
\text { 505). }\end{array}$ & $\begin{array}{l}\text { Symbolism group engaged } \\
\text { in imaginative, abstract } \\
\text { thinking. The control group } \\
\text { responses were less deep, } \\
\text { more confined to literal } \\
\text { interpretations. }\end{array}$ \\
\hline $\begin{array}{l}\text { Hannaford } \\
(2012)\end{array}$ & $\begin{array}{l}\text { Literacy / } \\
\text { Target } \\
\text { journal }\end{array}$ & $\begin{array}{l}\text { Eight children (ages } \\
8 \text { and 9) in a weekly } \\
\text { after-school } \\
\text { computer club. }\end{array}$ & $\begin{array}{l}\text { This teacher-researcher } \\
\text { conducted observations as } \\
\text { children chose and played } \\
\text { Internet games. Each child } \\
\text { was interviewed repeatedly } \\
\text { during club sessions. }\end{array}$ & $\begin{array}{l}\text { Imaginative engagement } \\
\text { was apparent throughout the } \\
\text { sessions. The researcher } \\
\text { determined "imaginative } \\
\text { play is, in some part, the } \\
\text { work of children } \\
\text { undertaking identity } \\
\text { practice" (p. 31). }\end{array}$ \\
\hline $\begin{array}{l}\text { Maine } \\
(2013) .\end{array}$ & $\begin{array}{l}\text { Literacy / } \\
\text { Target } \\
\text { journal }\end{array}$ & $\begin{array}{l}\text { Eight pairs of } \\
\text { primary-aged } \\
\text { children (Y1 and Y6) } \\
\text { from a school in a } \\
\text { small town in } \\
\text { England. }\end{array}$ & $\begin{array}{l}\text { The text given to children } \\
\text { in Year } 1 \text { (US } \\
\text { Kindergarten) was a } \\
\text { painting. The text given to } \\
\text { children in Year } 6 \text { was a } \\
\text { picture book. In pairs, } \\
\text { children were invited to }\end{array}$ & $\begin{array}{l}\text { The children co-constructed } \\
\text { meaning from the texts, } \\
\text { learning that multiple } \\
\text { interpretations were always } \\
\text { possible. Children can think } \\
\text { creatively and critically to } \\
\text { determine whether a }\end{array}$ \\
\hline
\end{tabular}




\begin{tabular}{|c|c|c|c|c|}
\hline & & & $\begin{array}{l}\text { discuss the texts. All } \\
\text { discussions were } \\
\text { videotaped and thematically } \\
\text { analyzed on three levels: } \\
\text { content, social dynamic, } \\
\text { and language. }\end{array}$ & $\begin{array}{l}\text { response is reasonable or } \\
\text { unreasonable in relation to } \\
\text { the text. }\end{array}$ \\
\hline $\begin{array}{l}\text { Lysaker \& } \\
\text { Sedberry } \\
\text { (2015). }\end{array}$ & $\begin{array}{l}\text { Literacy / } \\
\text { Target } \\
\text { journal }\end{array}$ & $\begin{array}{l}\text { Two boys in grade } 4 \\
\text { in Midwest, United } \\
\text { States. }\end{array}$ & $\begin{array}{l}\text { Students were individually } \\
\text { interviewed. After reading a } \\
\text { picture book, the student } \\
\text { was invited to retell the } \\
\text { story without prompts. } \\
\text { Next, the student was } \\
\text { shown a wordless version } \\
\text { of the text and asked to } \\
\text { retell the story again, using } \\
\text { the illustrations. The } \\
\text { researchers conducted a } \\
\text { thematic analysis, noting } \\
\text { ways retellings diverged } \\
\text { from the texts. The } \\
\text { differences were labeled } \\
\text { "personal dialogic } \\
\text { encounters." All responses } \\
\text { were coded for readers' use } \\
\text { of empathy and social } \\
\text { imagination in order to } \\
\text { understand the text. }\end{array}$ & $\begin{array}{l}\text { Reading images in } \\
\text { illustrations impacted the } \\
\text { students' recall of details. } \\
\text { Picture books can provide } \\
\text { opportunity for students to } \\
\text { learn about diverse } \\
\text { populations beyond their } \\
\text { own school. } \\
\text { Researchers found the } \\
\text { following methods } \\
\text { influenced the students' } \\
\text { understanding of people and } \\
\text { texts: Interactive read- } \\
\text { alouds with teacher- } \\
\text { provided open-ended } \\
\text { prompts, use of picture } \\
\text { books that leave room for } \\
\text { interpretation, individual } \\
\text { and paired retellings, } \\
\text { students dialoging with } \\
\text { peers after revisiting } \\
\text { recorded retellings }\end{array}$ \\
\hline
\end{tabular}

\section{Author Biography}

Carole Pelttari currently serves as Assistant Professor of Literacy Instruction at the College at Brockport, State University of New York. She taught elementary through middle school students for 20 years before entering higher education. She reads and imagines widely. 